\title{
Peranan Pemerintah dalam Menyejahterakan Masyarakat melalui Bantuan Sosial Perspektif Ekonomi Islam
}

\author{
Samud \\ Fakultas Syariah dan Ekonomi Islam \\ IAIN Syekh Nurjati Cirebon \\ Email: Samud_iaincrb@ymail.com
}

\begin{abstract}
Abstrak
Kemiskinan dan kebodohan ini menjadikan Indonesia Negara yang sedang mencari berbagai solusi dari gerbang pencerahan. Karena kebutuhan masyarakat akan sandang, pangan, dan juga papan tak lepas dari kewajiban Negara untuk memenuhinya. Untuk hal ini, Negara harus bersedia membuka berbagai peluang (kerja, program pengentasan kemiskinan, dan lain-lain). Jika tidak terpenuhi maka Indonesia menyimpan berbagai potensi penyakit social yang berdampak pada Negara anarkis. Dengan demikian, kehadiran pihak ketiga menjadi sangat penting untuk menjadi penengah antara pemerintah dan masyarakat dalam menyampaikan komunikasi yang berimbang dalam kaitannya terhadap pengembangan Negara bangsa dan masyarakat. Dengan hadirnya sebuah program untuk mengentaskkan kemiskinn yang terjadi dimasyarakat melalui berbagai macam bantuan social yang berhasil mengurangi angka kemiskinan.
\end{abstract}

\section{Kata Kunci: Kemiskinan, Bantuan Sosial, Ekonomi Islam}

\begin{abstract}
This poverty and ignorance makes Indonesia a country that is looking for various solutions from the gate of enlightenment. Because the community's needs for clothing, food, and also the board cannot be separated from the State's obligation to fulfill it. For this, the State must be willing to open various opportunities (employment, poverty alleviation programs, etc.). If it is not fulfilled, Indonesia will save a variety of potential social diseases that have an impact on the anarchist State. Thus, the presence of third parties is very important to mediate between the government and the community in delivering balanced communication in relation to the development of the nation state and society. With the presence of a program to alleviate poverty that occurs in the community through various kinds of social assistance that have succeeded in reducing poverty.
\end{abstract}

Keywords: Poverty, Social Aid, Islamic Economy 


\section{Pendahuluan}

Masalah yang paling besar dihadapi setiap negara adalah kemiskinan. ${ }^{1}$ Kemiskinan adalah salah satu masalah yang sulit dihadapi oleh para pembuat kebijakan. Keluarga-keluarga miskin mempunyai kemungkinan lebih besar menjadi tunawisma, ketergantungan obat, kekerasan dalam rumah tangga, masalah kesehatan, kehamilan remaja, buta huruf, pengangguran dan pendidikan yang rendah.

Kemiskinan dapat diartikan sebagai akibat dari ketiadaan demokrasi, yang mencerminkan hubungan kekuasaan yang menghilangkan kemampuan warga suatu negara untuk memutuskan masalah yang menjadi perhatian mereka sendiri, sehingga mayoritas penduduk kurang memperoleh alat-alat produksi (lahan dan tekhnologi) dan sumberdaya (pendidikan, kredit, dan akses pasar). Selain itu, kurangnya mekanisme yang memadai untuk akumulasi dan distribusi. $^{2}$

Kemiskinan adalah masalah sosial terbesar di dunia dan setiap negara berusaha untuk mengatasinya. Kemiskinan adalah faktor yang sangat menentukan maju tidaknya suatu negara. Terdapat masyarakat yang berkembang dan berbahagia jika kebanyakan penduduknya berada dalam kemiskinan serta kesengsaraan, maka dari itu kemiskinan tidak sekedar hanya masalah tidak terpenuhinya kebutuhan dasar hidup masyarakat melainkan juga menjabarkan situasi pendidikan dan kesehatan yang tidak baik, penurunan di bidang ilmu pengetahuan dan komunikasi, ketidakmampuan menegakkan hak-hak asasi manusia dan politik, dan belum terdapatnya kehormatan, kepercayaan dan harga diri. ${ }^{3}$

Kemiskinan membuat seseorang belum bisa melengkapi keperluan dasar dirinya dan keluarganya yang mencangkup

1 Sulastomo, Sistem Jaminan Nasional: Mewujudkan Amanat Konsitusi, (Jakarta: PT.Gramedia Pustaka Utama, 2011), hlm.14

${ }^{2}$ Nurul Huda, dkk., Ekonomi Pembangunan Islam, (Jakarta: Kencana, 2015), hlm. 20-21

${ }^{3}$ Bachtiar Chamsyah, Kemiskinan Sebagai Isu Global. Artikel. http://www.socialwelfare.fisip.ui.ac.id kebutuhan fisik, mental dan sosial. Dengan tidak terpenuhinya kebutuhan dasar manusia akan berimplikasi pada keterlantaran anggota keluarga dan ketunaan sosial. Rumah merupakan salah satu keperluan dasar manusia yang tingkat kepentingannya lebih rendah dari sandang dan pangan. Dalam konteks penyelenggaraan perumahan yang terdesentralisasi, saat ini belum tersedia sistem penyediaan perumahan di daerah yang tanggap terhadap perkembangan kebutuhan. Hal ini disebabkan belum berkembangnya pemahaman bahwa perumahan juga merupakan urusan publik selain urusan individu. $^{4}$

Disadari atau tidak bahwa setiap manusia di dunia ini tidak akan bisa lepas dari dunia perekonomian karena hal ini merupakan salah satu fitrah manusia dalam menjalani kehidupannya. ${ }^{5}$ Ekonomi merupakan aspek penting yang dapat menunjang kemajuan suatu bangsa. Bangsa yang besar adalah bangsa yang mampu menumbuhkan dan memajukan sektor ekonomi baik sektor formal maupun informal untuk memperhatikan pemerataan pendapatan bagi warga negaranya.

Salah satu prinsip yang penting dalam sistem ekonomi Islam adalah negara memiliki kekuasaan dan wewenang untuk mengintervensi kehidupan ekonomi masyarakat. Negara bertanggungjawab secara langsung dalam memelihara masyarakatnya dan menyediakan berbagai sarana untuk mempertahankan standar hidup yang layak.

Lahirnya otonomi daerah menumbuhkan harapan baru bagi pemerintah serta masyarakat untuk membangun dan mengembangkan potensi yang dimiliki suatu daerah dalam rangka pencapaian kesejahteraan masyarakat melalui perannya dalam pembangunan perekonomian dalam pelayanan dan pemberdayaan masyarakat.

${ }^{4}$ Badan Perencanaan Pembangunan Nasional. 2003. Infrastruktur Indonesia; Sebelum, Selama dan Pasca Krisis. Jakarta: Perum Percetakan Negara RI.

5 Arifin Johan, Etika Bisnis Islami (Semarang: Walisongo Press, 2009), hlm. 31. 
Baqir al-Sadr sebagaimana dikutip $\mathrm{M}$. Umer Chapra mengatakan bahwa intervensi pemerintah dalam ruang lingkup kehidupan berekonomi adalah penting dalam menjamin keselarasan dengan norma-norma Islam. Sebagian besar ulama menekankan pentingnya regulasi aktivitas ekonomi dan pasar darisudut pandang syari'ah, demi menjamin tegaknya keadilan dan aturan main yang tidak memihak. ${ }^{6}$

\section{Pembahasan \\ Peran Pemerintah}

Peran adalah laku; hal berlaku/bertindak; pemeran; pelaku; pemain (film/drama). ${ }^{7}$ Selain itu juga mempunyai sinonim kata seperti kedudukan, tugas, karakter, kontribusi, perwatakan. ${ }^{8}$ Dalam tinjauan organisasi, peran merupakan komponen dari sistem organisasi yang merupakan perilaku kerja yang dapat menghasilkan beberapa perubahan. ${ }^{9}$ Jadi dapat disimpulkan bahwa peran merupakan suatu tindakan yang memberikan kontribusi yang dapat menghasilkan beberapa perubahan. Definisi tersebut sangat relevan dengan pemerintah daerah yang memiliki peran dalam meningkatkan fungsi pasar tradisional dalam mendorong berkembangnya kegiatan perekonomian masyarakat.

Peranan adalah berasal dari kata peran (dipinjam dari istilah seni film/drama), yaitu laku, hal berlaku,/bertindak, pemeran, pelaku, pemain sedangkan peranan (role) adalah fungsi, kedudukan, bagian kedudukan. ${ }^{10}$ Dalam konteks kelembagaan lain, peranan adalah aspek dinamis suatu

${ }^{6}$ Mustafa Edwin Nasution, dkk, Pengenalan Ekonomi Isam (Jakarta: Kencana, 2006), hlm. 190.

${ }^{7}$ Hendro Darmawan, Kamus Ilmiah Populer Lengkap, (Yogyakarta : Bintang Cemerlang, 2013), hlm. 554.

Kamus besar, definisi peran, dalamwww.artikata.com, diakses pada tanggal 8 Maret 2015, pukul 17.00.

9 Teori peran menurut Dougherty dan Pritchard, dalam www.google.co.id, definisi peranmenurut para ahli, diakses pada tanggal 8 Maret 2015, pukul 19.25.

${ }^{10}$ Dahlan Al Barry. Kamus Modern Bahasa Indonesia. Yogyakarta: Arkola. 1994), hlm. 501 lembaga, atau peranan mewakili tata institusional (institutional oreder) suatu lembaga (dalam hal ini pemerintah). ${ }^{11}$ Jadi, peranan adalah pelaksanaan fungsi oleh pemerintah Pengertian pemerintah daerah adalah Gubemur, Bupati, atau walikota, dan Perangkat daerah sebagai unsur penyelenggara pemerintahan daerah.

Pemerintah berasal dari kata "perintah" yang berarti sesuatu yang harus dilaksanakan. Di dalam bahsa Inggris, istilah pemerintahan dan pemerintah tidak memiliki perbedaan yang disebut dengan "government". Istilah ini bersumber dari latin yaitu "gubernauculum" yang berarti kemudi.

Kata government dapat bermakna; melaksanakan wewenang pemerintahan, cara atau sistem memerintah, fungsi atau kekuasaan untuk memreintah, wilayah atau Negara yang diperintah, badan yang terdiri dari orang-orang yang melaksanakan wewenang dan administrasi hukum dalam suatu Negara. ${ }^{12}$ Dalam hal ini, pemerintah yang dimaksud adalah Pemerintah Daerah Kabupaten Brebes khususnya Dinas Perindustrian dan Perdagangan sebagai penyelenggara urusan pemerintahan oleh Pemerintah Daerah.

Pemerintahan modern pada hakekatnya adalah pelayanan kepada masyarakat, pemerintahan tidak diadakan untuk melayani dirinya sendiri. Pemerintah dituntut mampu memberikan pelayanan kepada masyarakatnya dan menciptakan kondisi yang memungkinkan setiap orang dapat mengembangkan kemampuan dan kreativitasnya demi mencapai kemajuan bersama. $^{13}$

Pemerintah merupakan sesuatu yang berhubungan langsung dalam kehidupan bermasyarakat baik hubungan antara

${ }^{11}$ Berger, PL dan T. Luckmann. 1982. Realitas Konstrukti Sosial, diterjemahkan oleh Syarwani, dkk. Jakarta Sinar Harapan. 1982), hlm. 92

Konsep-dasar-pemerintah-danpemerintahan.html, diakses pada tanggal 21 April 2015 pukul 19.55 WIB.

${ }^{13}$ Dina Damayanti, Peran Pemerintah Daerah Terhadap Perkembangan Koperasi di Kabupaten Kendal, jurnal Majalah Ilmiah Inspiratif, Vol.2 No.2 Januari 2016, hlm. 3 
manusia dengan setiap kelompok masyarakat maupun keluarga. Berkenaan dengan hubungan masyarakat, pasti akan selalu menyangkut dengan unsur-unsur kebutuhan dasar manusia seperti makanan, pakaian dan sebagainya. Namun, apabila masyarakat tidak mampu dalam memenuhi segala kebutuhan dasarnya maka pemerintah harus dapat mengatasi permasalahan tersebut dengan menjalankan segala fungsinya sebagai pemerintah. ${ }^{14}$

\section{Kesejahteraan Masyarakat}

Kesejahteraan adalah rasa tentram seseorang karena terpenuhinya hajat-hajat hidup lahir dan batin, kesejahteraan lahir didasarkan pada standar universal menyangkut kesehatan, sandang, pangan dan papan (kesejahteraan ekonomi dan sosial), sedangkan kesejahteraan batin menyangkut persepsi yang bersifat intelektual, emosional maupun spiritual seseorang. Kesejahteraan bukan alat perjuangan tapi tujuan perjuangan. $^{15}$

Kesejahteraan merupakan suatu keadaan yang menunjukkan bahwa masyarakat sejehtera dengan terpenuhinya kebutuhan secara materil dan sosial. Berbicara kesejahteraan akan berkaitan dengan konteks kemiskinan, namun tidak dalam semua hal. Semakin tinggi tingkat kesejahteraan hidup masyarakat maka semakin rendah kemiskinan. Semakin tinggi angka kemiskinan yang terjadi semakin banyak masyarakat yang tidak sejahtera. ${ }^{16}$

Menurut Anwar Abbas dalam bukunya yang berjudul Bung Hatta dan Ekonomi Islam, "orang merasa hidupnya

14 Rahmaniar dkk, Peran Pemerintah Terhadap Lanjut Usia Pada Panti Sosial Tresna Werdha Sinta Rangkang Di Kota Palangka Raya, IAIN Palangka RayaJurnal Al-Qardh, Vol. 2, No. 4, Desember 2016, hlm. 120

15 Garda Maeswara, Biografi Prolitik Susilo Bambang Yudhoyono, (Jakarta: Penerbit Narasi, 2009), hlm. 246

16 Baskoro Wicaksono, Peran Pemerintah Dalam Meningkatkan Kesejahteraan Petani Salak di Desa Tinjoman Lama Kecamatan Padangsidimpuan Hutaimbaru Kota Padang Sidimpuan Tahun 2014, Hasil Penelitian Jurusan Ilmu Pemerintahan FISIP Universitas Riau, 2014, hlm. 12 sejahtera apabila ia merasa senang, tidak kurang suatu apapun dalam batas yang mungkin dicapainya, jiwanya tentram lahir dan batin terpelihara, ia merasakan keadilan dalam hidupnya, ia terlepas dari kemiskinan yang menyiksa dan bahaya kemiskinan yang mengancam". 17

Kesejahteraan masyarakat adalah suatu kondisi yang memperlihatkan tentang keadaan kehidupan masyarakat yang dapat dilihat dari standar kehidupan masyarakat. Menurut Sen Pressmen kesejahteraan masyarakat adalah jumlah dari pilihan yang dipunyai masyarakat dan kebebasan untuk memilih diantara pilihan-pilihan tesebut dan akan memaksimum apabila mayarakat dapat membaca, makan dan memberikan hak suaranya.

Pembangunan yang dilakukan pemerintah dan masyarakat bertujuan untuk meningkatkan kesejahteraan sosial bagi seluruh rakyat Indonesia. Indonesia merupakan negara berkembang, yang merencanakan perubahan-perubahan dalam masyarakat yang adil dan makmur, material maupun spiritual untuk mengentaskan masalah-masalah sosial yang semakin hari semakin meningkat. Untuk mencapai tujuan tersebut perlu adanya pelaksanaan pembangunan ekonomi yang memperlihatkan keserasian, keselarasan dan keseimbangan unsur-unsur pemerataan sebuah pembangunan dan pertumbuhan ekonomi. dalam hal ini sektor usaha kecil atau sektor informal sangat berperan penting dan strategis dalam pembangunan nasional, baik dari segi kuantitas maupun dari segi kemampuannya dalam peningkatan pendapatan dan penyerapan tenaga kerja untuk mewujudkan pemerataan hasil pembangunan, termasuk pengentasan kemiskinan. ${ }^{18}$

17 Kementerian dalam Negeri Republik Indonesia, Penjelasan I : Pemantauan, Pengawasan Evaluasi, Audit dan Pelaporan (PEtunnjuk Teksis Operasional), Direktorat Jendral Pemberdayaan

Masyarakat dan Desa, hlm. 5

18 Khairuddin, Sosiologi Keluarga, (Yogyakarta: Liberty, 2002), hlm. 48. 
Kementerian

Koordinator

Kesejahteraan Rakyat memberi pengertian sejahtera yaitu suatu kondisi masyarakat yang telah terpenuhi kebutuhan dasarnya. Kebutuhan dasar tersebut berupa kecukupan dan mutu pangan, sandang, papan, kesehatan, pendidikan, lapangan pekerjaan, dan kebutuhan dasar lainnya seperti lingkungan yang bersih, aman dan nyaman. Juga terpenuhinya hak asasi dan partisipasi serta terwujudnya masyarakat beriman dan bertaqwa kepada Tuhan Yang Maha Esa. ${ }^{19}$

Menurut Badan Pusat Statistik (BPS), indikator yang dapat digunakan untuk menilai tingkat kesejahteraan masyarakat meliputi: pendapatan, konsumsi atau pengeluaran rumah tangga, keadaan tempat tinggal, fasilitas tempat tinggal, kesehatan anggota keluarga, kemudahan mendapatkan pelayanan kesehatan, kemudahan memasukkan anak ke jenjang pendidikan, dan kemudahan mendapatkan fasilitas transportasi. Dalam penelitian ini, kesejahteraan yang dimaksud adalah terpenuhinya kebutuhan sandang, pangan, papan, pendidikan, serta kesehatan.

Masyarakat adalah pergaulan hidup manusia; sehimpunan manusia yang hidup bersama dalam suatu tempat dengan ikatanikatan aturan yang tertentu; orang banyak; khalayak ramai. ${ }^{20}$ Sedangkan Horton dan Hunt mendefinisikan masyarakat sebagai sekumpulan manusia yang secara relative mandiri, yang hidup bersama-sama cukup lama, yang mendiami suatu wilayah mandiri, memiliki kebudayaan yang sama, dan melakukan sebagian besar kegiatannya dalam kelompok tersebut. ${ }^{21}$

Secara umum, istilah kesejahteraan sosial sering diartikan sebagai kondisi sejahtera, yaitu suatu keadaan terpenuhinya segala bentuk kebutuhan hidup, khususnya yang bersifat mendasar seperti makanan,

\footnotetext{
19 www.menkokesra.go.id., diakses pada tanggal 21 April 2015 pukul 16.24 WIB.

20 Hoetomo, Kamus Lengkap Bahasa Indonesia (Surabaya: Mitra Pelajar, 2005), hlm. 336.

${ }^{21}$ Horton dan Hunt, lihat dalam Damsar, dan Indrayani, Pengantar Sosiologi Ekonomi (Jakarta: Kencana, 2009), hlm. 5.
}

pakaian, perumahan, pendidikan dan perawatan kesehatan. Pengertian seperti ini menempatkan kesejahteraan sosial sebagai tujuan akhir dari suatu kegiatan pembangunan.

Kesejahteraan sosial yang digambarkan al-Qur`an tercermin dari surga yang dihuni oleh Adam dan istrinya, sesaat sebelum turunnya mereka menjalankan tugas kekhalifahan di muka bumi. Keadaan Adam dan istrinya di surga merupakan bayangbayang impian manusia akan kehidupan yang nyaman, tercukupinya pangan, sandang dan papan, dalam artian tidak kelaparan, dahaga, telanjang, dan kepanasan. Tercukupinya kebutuhan Adam selama di surga merupakan unsur pertama dan utama kesejahteraan social. $^{22}$

Keadaan Adam dan istrinya yang tercukupi kesejahteraan sosialnya selama di surga dapat kita lihat dalam firman Allah surat Thaha ayat 117-119.

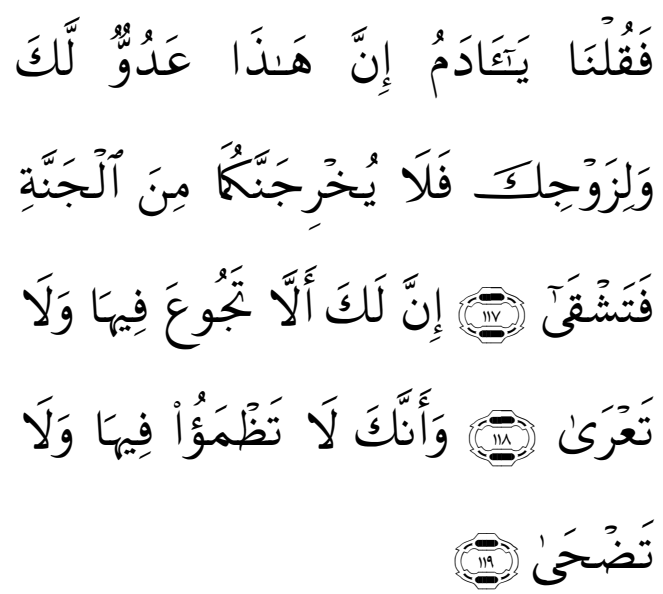

"Kemudian Kami berfirman, "Wahai Adam, sesungguhnya ini (iblis) adalah musuh bagimu dan bagi istrimu, maka sekali-kali jangan sampai ia mengeluarkan kamu berdua dari surga, nanti kamu celaka. Sungguh, ada jaminan untukmu di sana, engkau tidak akan kelaparan dan tidak akan telanjang. Dan sungguh, di sana engkau tidak akan merasa dahaga dan tidak akan ditimpa panas matahari".(QS. Thaha: 117-119)

22 Suisyanto, Model-model Kesejahteraan..., hlm. 35 
Berdasarkan ayat diatas, tergambar bahwa kehidupan di surga merupakan kehidupan yang aman, sentosa dan makmur. Kesejahteraan yang ada di surga merupakan sesuatu yang telah ada karena diberikan oleh Allah sebagai karunia untuk penghuni surga tanpa harus diusahakan, sedangkan kesejahteraan yang di bumi bukanlah sesuatu yang ada dengan sendirinya akan tetapi sesuatu yang harus diusahakan, dicari dan diperjuangkan untuk dimiliki dan dinikmati. Menurut Sayyid Qutb, sistem kesejahteraan sosial yang diajarkan oleh Islam bukan sekedar bantuan keuangan apapun bentuknya. Bantuan keuangan hanyalah satu dari sekian bentuk bantuan yang dianjurkan Islam. $^{23}$

Kesejahteraan juga dijelaskan

dalam Al-Qur`an surat Al-A`raf ayat

10.

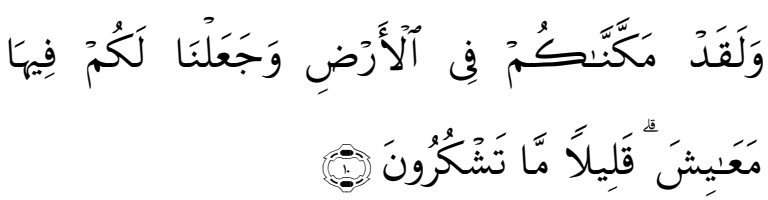

"Dan sungguh, Kami telah menempatkan di bumi dan di sana Kami sediakan (sumber) penghidupan untukmu. (tetapi) sedikit kamu bersyukur”. (QS. Al-A`raf: 10)

Pada ayat di atas, Allah mengingatkan kepada hambaNya untuk mensyukuri nikmat yang telah diberikanNya. Nikmat itu adalah sarana untuk mendapatkan kesejahteraan yang berupa bumi yang diciptakanNya untuk tempat tinggal, tempat untuk memenuhi segala tujuan hidup, menguasai tanah, hasil tanamannya, binatang-binatangNya, dan tambangtambangnya yang semua itu nikmat yang Allah berikan.

Menurut Undang-undang No 11 Tahun 2009 tentang Kesejahteraan Sosial, Kesejahteraan sosial adalah kondisi terpenuhinya kebutuhan material, spiritual

${ }^{23}$ Sayyid Qutb, Dirasah Islamiyah. (Kairo: alMa`arif, 1967), hlm. 63 dan sosial warga negara agar dapat hidup layak dan mampu mengembangkan diri, sehingga dapat melaksanakan fungsi sosialnya. Permasalahan kesejahteraan sosial yang berkembang dewasa ini menunjukkan bahwa ada warga negara yang belum terpenuhi hak atas kebutuhan dasarnya secara layak karena belum memperoleh pelayanan sosial dari negara. Akibatnya, masih ada warga negara yang mengalami hambatan pelaksanaan fungsi sosial sehingga tidak dapat menjalani kehidupan secara layak dan bermartabat. Di samping itu, kebahagiaan dan kesejahteraan hidup yang harus tercakup di dalamnya adalah adanya rasa tenteram, aman dan damai. Seseorang akan merasa bahagia apabila terpenuhi unsur-unsur tersebut dalam kehidupannya. Sedangkan sejahtera diartikan sebagai keadaan lahiriah yang diperoleh dalam kehidupan duniawi yang meliputi : kesehatan, sandang, pangan, papan, perlindungan hak asasi dan sebagainya. Jadi seseorang yang sejahtera hidupnya adalah orang yang memelihara kesehatannya, cukup sandang, pangan dan papan. Mereka juga diterima dalam pergaulan masyarakat yang beradab dan hak-hak asasinya terlindungi oleh norma agama, norma hukum dan norma susila.

Kesejahteraan sosial memiliki banyak makna yang berbeda walaupun substansinya tetap sama. Kesejahteraan sosial pada dasarnya memiliki tiga konsepsi yaitu:

a. Kondisi kehidupan atau keadaan sejahtera yaitu terpenuhinya kebutuhan-kebutuhan jasmaniah, rohaniah dan social.

b. Institusi, arena atau bidang kegiatan yang melibatkan lembaga kesejahteraan sosial dan berbagai profesi kemanusiaan yang menyelenggarakan usaha kesejahteraan sosial dan pelayanan sosial.

c. Aktivitas, yakni kegiatan-kegiatan usaha yang terorganisir untuk mencapai kondisi sejahtera. ${ }^{24}$

24 Edi Suharto, Membangun Masyarakat Memberdayakan Rakyat (Kajian Strategis Pembangunan Kesejahteraan Sosial \& Pekerjaan Sosial), (Bandung: PT Refika Aditama. 2005), hlm. 2 
Dengan demikian kesejahteraan sangat erat hubungannya dengan perkembangan ekonomi masyarakat, karena dengan adanya kebijakan sosial, pelayanan untuk memenuhi kebutuhan masyarakat akan menjadi baik.

Dalam penjelasan di atas kesejahteraan sosial sulit untuk didefinisikan, meskipun begitu bukan berarti kesejahteraan sosial harus didefinisikan karena menyangkut pokok pembicaraan tentang pekerjaan sosial yang mengupayakan kesejahteraan bagi masyarakat.

Fungsi-fungsi kesejahteraan sosial bertujuan untuk menghilangkan atau mengurangi tekanan-tekanan yang diakibatkan terjadinya perubahan-perubahan sosio-ekonomi, menghindarkan terjadinya konsekuensi-konsekuensi sosial negatif akibat pembangunan serta menciptakan kondisi-kondisi yang mampu mendorong peningkatan kesejahteraan masyarakat. ${ }^{25}$

Berdasarkan penjelasan kesejahteraan yang sudah dipaparkan diatas, dapat diambil kesimpulan bahwa yang dimaksud dengan kesejahteraan adalah keadaan terpenuhinya segala bentuk kebutuhan hidup, baik kebutuhan yang bersifat mendasar seperti makanan, pakaian, perumahan, pendidikan dan perawatan kesehatan. Kesejahteraan merupakan cita-cita sosial setiap manusia yang tidak hanya sekedar diangankan untuk dimiliki tetapi juga harus diusahakan, karena tanpa ada usaha dan kerja sama yang baik kesejahteraan sosial hanyalah fatamorgana.

\section{Ekonomi Islam}

Menurut Mannan, ilmu ekonomi Islam merupakan ilmu pengetahuan sosial yang mempelajari masalah-masalah ekonomi rakyat yang diilhami oleh nilai-nilai Islam. Ekonomi syari'ah tidak hanya membahas tentang aspek perilaku manusia yang berhubungan dengan cara mendapatkan uang dan membelanjakannya, tetapi juga

${ }^{25}$ Isbandi Rukminto Adi. Ilmu Kesejahteraan Sosial dan Pekerjaan Sosial: Pengantar Pada Pengertian dan Beberapa Pokok Bahasan. (Jakarta: FISIP UI Press 2005), hlm. 5-10 membahas segala aspek ekonomi yang membawa kepada kesejahteraan umat. ${ }^{26}$

Menurut Baqir ash-Sadr pemilikan negara mendominasi system ekonomi Islam yang pada akhirnya akan mendorong lahirnya sebuah gagasan bahwa peran pemerintah dalam bidang ekonomi sangatlah penting. Dalam hal ini, beberapa fungsi pokok pemerintah dalam bidang ekonomi antara lain mengatur sistem distribusi kekayaan berdasarkan pada kemauan dan kapasitas kerja masing-masing individu dalam masyarakat, mengintegrasikan aturan hukum Islam dalam setiap penggunaan dan pengelolaan sumber daya alam, dan membangun sistem kesejahteraan masyarakat melalui terjaminnya keseimbangan sosial dalam masyarakat. ${ }^{27}$

Komitmen Islam yang demikian mendalam terhadap persaudaraan dan keadilan menyebabkan konsep kesejahteraan (falah) bagi semua umat manusia sebagai suatu tujuan pokok Islam. Kesejahteraan ini meliputi kepuasan fisik sebab kedamaian mental dan kebahagiaan hanya dapat dicapai melalui realisasi yang seimbang antara kebutuhan materi dan rohani dari personalitas manusia. ${ }^{28}$

Islam menekankan bahwa manusia adalah makhluk sosial, dan karena itu dia dapat mengembangkan kepribadiannya hanya dalam masyarakat. Shalat lima kali sehari dalam Islam adalah wajib dalam jama'ah, sedemikian pula pergi ziarah haji ke Mekkah wajib bagi yang mampu. Orang Islam diwajibkan untuk shalat lima kali sehari tetapi juga diberitahukan melaksanakan perdagangan (usaha) mereka dan berdagang setelah shalat. $^{29}$ Islam mengakui kesejahteraan individu dan kesejahteraan sosial masyarakat yang saling melengkapi satu dengan yang lain, bukannya

${ }^{26}$ Nurul Hak, Ekonomi Islam Hukum Bisnis Syari'ah (Yogyakarta: Teras, 2011), hlm. 7.

27 Nur Chamid, Jejak Langkah Sejarah Pemikiran Ekonomi Islam (Yogyakarta: Pustaka Pelajar, 2010), hlm. 324-325.

28 Moh. Thahah Hasan, Islami dalam Perspektif Sosio Kultural, (Jakarta: Lantabora Press, 2005). hlm. 161

${ }^{29}$ Departemen Agama RI, Op.Cit. hlm. 162 
saling bersaing dan bertentangan antar mereka. ${ }^{30}$

Kepatuhan ini membantu manusia merealisasikan potensi dirinya, dengan berusaha semaksimal mungkin untuk mengembangkan diri dalam menciptakan kesejahteraan. Kesejahteraan yang bukan untuk kepentingan pribadi namun kesejahteraan bagi seluruh umat manusia. ${ }^{31}$

Kesejahteraan dalam pandangan Islam tidak hanya dinilai dari ukuran material saja, tetapi dinilai juga dari ukuran non-material seperti: terpenuhinya kebutuhan spiritual, terpeliharanya nilai-nilai moral dan terwujudnya keharmonisan sosial. Imam Ghazali mendefinisikan aspek dari fungsi kesejahteraan sosialnya dalam rangka sebuah hirarki utilitas individu dan sosial yang tripartite meliputi: kebutuhan pokok (dharuriyat), kesenangan atau kenyamanan (hajiyat), dan kemewahan (tahsiniyat). ${ }^{32}$

Pemerintahan yang baik adalah yang mampu memfokuskan pada pemenuhan kesejahteraan yang adil dan merata. Pemenuhan kesejahteraan yang adil dan merata hanya dapat dicapai dengan pertumbuhan ekonomi yang berkesinambungan disertai dengan stabilitas ekonomi yang mantap. Pembangunan ekonomi jelas sangat mempengaruhi tingkat kemakmuran suatu negara. Oleh karena itu pembangunan ekonomi yang disertai dengan suatu kebijakan tentunya bertujuan untuk mengubah kondisi negara ke arah yang lebih baik lagi. ${ }^{33}$

\section{Program Pengentasan Kemiskinan Pengertian Kemiskinan}

30 M. Umer Chapra, Islam Pembangunan Ekonomi, (Jakarta, Gema Insani Press, 2000), hlm. 8

31 Afzalur Rahman, Doktrin Ekonomi Islam Jilid I, hlm.54

32 Ruslan Abdul Ghofur Noor, Konsep Distribusi dalam Ekonomi Islam, (Yogyakarta: Pustaka Pelajar, 2013), hlm. 63-64

33 Sitti Mawar, Fungsi Kebijakan Ekonomi Pemerintah Kota Banda Aceh Terhadap Kesejahteraan Masyyarakat Menurut Ibnu Kaldum, Jurnal UIN Ar-Raniry Banda AcehProdi Ilmu Hukum Pada Fakultas Syari'ah dan Hukum, 2016, hlm. 3
Kemiskinan adalah suatu kondisi ketidakmampuan secara ekonomi untuk memenuhi standar hidup rata-rata masyarakat di suatu daerah. Kondisi ketidakmampuan ini ditandai dengan rendahnya kemampuan pendapatan untuk memenuhi kebutuhan pokok baik berupa pangan, sandang, maupun papan. Kemampuan pendapatan yang rendah ini juga akan berdampak berkurangnya kemampuan untuk memenuhi standar hidup rata-rata seperti standar kesehatan masyarakat dan standar pendidikan. ${ }^{34}$

Kemiskinan yang terjadi didasarkan oleh seseorang yang tidak memiliki pekerjaan (penggangguran). Tingkat pengangguran sangat berhubungan dengan tingkat kemiskinan, apabila tingkat pengangguran suatu negara tinggi secara tidak langsung tingkat kemiskinan negara tersebut juga tinggi. Berdasarkan hal tersebut, pemerintah sebagai pengelola formal negara adalah satu-satu nya pihak yang berhak untuk mengelola dan menyelesaikan permasalahan kemiskinan. Salah satu cara mengurangi tingkat kemiskinan ialah dengan mengurangi tingkat pengangguran. ${ }^{35}$

Berdasarkan Undang-Undang No. 24 Tahun 2004, kemiskinan adalah kondisi sosial ekonomi seseorang atau sekelompok orang yang tidak terpenuhinya hak-hak dasarnya untuk mempertahankan dan mengembangkan kehidupan yang bermartabat. Kebutuhan dasar yang menjadi hak seseorang atau sekelompok orang meliputi kebutuhan pangan, kesehatan, pendidikan, pekerjaan, perumahan,air bersih, pertanahan, sumber daya alam, lingkungan hidup, rasa aman dari perlakuan atau ancaman tindak kekerasan, dan hak untuk

${ }^{34}$ Sam F. Poli, Memperdayakan kaum Miskin, (Yogyakarta; 2005, h.75

35 Adasiha Arwan dkk, Pengaruh Kebijakan Pemerintah Terhadap Tingkat Kewirausahaan di Indonesia (Studi pada Program Kredit Usaha Rakyat Periode Tahun 2008-2014), Malang: Jurnal Administrasi Bisnis (JAB) Vol. 60 No. 3 Juli 2018, hlm. 11 
berpartisipasi dalam penyelenggaraan kehidupan sosial dan politik.

Laporan Bidang Kesejahteraan Rakyat yang dikeluarkan oleh Kementrian Bidang Kesejahteraan (Kesra) tahun 2004 menerangkan pula bahwa kondisi yang disebut miskin ini juga berlaku pada mereka yang bekerja akan tetapi pendapatannya tidak mencukupi untuk memenuhi kebutuhan pokok/dasar. Definisi kemiskinan kemudian dikaji kembali dan diperluas berdasarkan permasalahan-permasalahan kemiskinan dan faktor-faktor yang selanjutnya menyebabkan menjadi miskin. Definisi kemiskinan yang dikemukakan oleh Chambers adalah definisi yang saat ini mendapatkan perhatian dalam setiap program pengentasan kemiskinan di berbagai negaranegara berkembang dan dunia ketiga. Pandangan yang dikemukakan dalam definisi kemiskinan dari Chambers menerangkan bahwa kemiskinan adalah suatu kesatuan konsep (integrated concept) yang memiliki lima dimensi, yaitu:

a. Kemiskinan (proper)

b. Ketidakberdayaan (power less)

c. Karentanan manghadapi situasi darurat (state of emergency)

d. Ketergantungan (dependence)

e. Keterasingan (isolation)

\section{Program Beras untuk Masyarakat Miskin (RASKIN)}

Raskin merupakan beras yang disubsidikan oleh pemerintah yang dijual dengan harga yang lebih murah jika dibandingkan harga beras dipasaran. Awal mula realisasi beras miskin pada tahun 1998 ketika terjadi krisis moneter, yang bertujuan untuk mempererat ketahanan pangan rumah tangga terutama rumah tangga miskin (RTM). ${ }^{36}$

Raskin merupakan subsidi pangan dalam bentuk beras yang diperuntukkan bagi rumahtangga berpenghasilan rendah sebagai upayadari pemerintah untuk meningkatkan ketahanan pangan dan memberikan perlindungan sosial padarumah tangga

36 http://bulog.go.id/,"Program Beras untuk Keluarga Miskin”, hlm..4-6, diakses 17 Juli 2018 sasaran. Keberhasilan Program Raskin diukur berdasarkantingkat pencapaian indikator 6T, yaitu: tepat sasaran, tepat jumlah, tepat harga, tepat waktu, tepat kualitas, dan tepat administrasi.Program ini bertujuan untuk mengurangi beban pengeluaran Rumah Tangga Sasaran (RTS) melalui pemenuhan sebagian kebutuhan pangan pokok dalam bentuk beras dan mencegah penurunan konsumsienergi dan protein.Selain itu raskin bertujuan untukmeningkatkan/membuka akses pangan keluargamelalui penjualan beras kepada keluarga penerima manfaat dengan jumlah yang telah ditentukan. ${ }^{37}$

Program raskin adalah program nasional lintas sektoral yang baik vertical (Pemerintah Pusat sampai dengan Pemerintah Daerah) maupun horizontal (Lintas Kemmenterian/Lembaga), sehingga semua pihak yang berkait bertanggunng jawab sesuai dengan tugas pokok dan fungsi masing-masing untuk kelancaran pelaksanaan dan pencapaian tujuan program raskin. ${ }^{38}$

Penyandang Masalah Kesejahteraan Sosial dapat dikatakan seseorang, keluarga atau kelompok masyarakat yang karena suatu hambatan, kesulitan atau gangguan tidak dapat melaksanakan fungsi sosialnya, sehingga tidak dapat terpenuhi kebutuhan hidupnya baik jasmani, rohani dan sosial secara memadai dan wajar. Hambatan, kesulitan dan gangguan tersebut dapat berupa kemiskinan, keterlantaran, kecacatan, ketunaan sosial, keterbelakangan, keterasingan/keterpencilan dan perubahan lingkungan (secara mendadak) yang kurang mendukung, seperti terjadinya bencana. ${ }^{39}$

\section{Program Keluarga Harapan (PKH)}

\footnotetext{
http://www.tnp2k.go.id/id, "Beras Raskin”,hlm.1, diakses 17 Juli 2018 http://www.tnp2k.go.id/tanya-jawabprogram-raskin/page1, diakses 24 Juli 2018

${ }^{39}$ Ambiro Puji Asmaroini, Efektivitas Bantuan Sosial Bagi Masyarakat Kampung Idiot Di Desa Karangpatihan Kecamatan Balong Kabupaten Ponorogo, hlm. 8
} 
Sejak tahun 2007 Pemerintah Indonesia telah melaksanakan Program Keluarga Harapan (PKH). Program serupa telah dilaksanakan dan cukup berhasil di beberapa negara yang dikenal dengan Conditional Cash Transfers (CCT) atau bantuan tunai bersyarat. PKH bukan kelanjutan program Subsidi Langsung Tunai (BLT) yang diberikan dalam rangka membantu rumah tangga miskin mempertahankan daya belinyapada saat pemerintah melakukan penyesuaian harga BBM. PKH lebih dimaksudkan sebagai upaya membangun sistem perlindungan sosial kepada masyarakat miskin. Berdasarkan pengalaman negara-negara lain, program serupa sangat bermanfaat terutama bagi keluarga dengan kemiskinan kronis. Namun tujuan dari PKH untuk mengentaskan kemiskinan itu sendiri merupakan harapan jangka panjang yang ingin dicapai. Hal ini tidak berarti bahwa tujuan jangka panjang tersebut sia-sia, namun tentu PKH tidak bisa berdiri sendiri untuk mencapai target tersebut. Perlu ada program-program pengentasan kemiskinan lainnya yang betul-betul bersifat memberdayakan agar kondisi keberdayaan masyarakat dapat tercapai. ${ }^{40}$

Pembangunan erat kaitannya dengan pemenuhan kebutuhan masyarakat agar terciptannya sebuah kesejahteraan. Dalam mewujudkan sebuah kesejahteraan masyarakat, pemerintah harus memperhatikan masalah kemiskinan, karena kemiskinan merupakan hal yang tidak dapat dilepaskan dari masalah pemenuhan kebutuhan hidup. Kesejahteraan masyarakat dapat diukut dengan kemampuan masyarakat memenuhi kebutuhan hidupnya.

Program Keluarga Harapan atau disingkat PKH adalah salah satu dari sekian program pemerintah dalam mengentas kemiskinan di Indonesia dalam bentuk bantuan langsung tunai kepada masyarakat penerima yang dikategorikan sebagai rumah

40 Syahputra Adisanjaya dll, Program Keluarga Harapan (PKH): Antara Perlindungan Sosial dan Pengentasan Kemiskinan, Prosiding KS: Riset \& PKM Volume: 4 ISSN: 2442-4480, hlm. 90 tangga sangat miskin. Program ini boleh juga dikatakan kalau terlalu ekstrim menjadi "tameng" kebijakan populis pemerintah. PKH dapat dikatakan juga merupakan senjata sakti untuk menahan kemarahan rakyat terhadap pemerintah yang menaikkan harga BBM dan mencabut subsidi atasnya. Pemerintah lalu menyebutnya dengan dana kompensasi BBM. ${ }^{41}$

Program Keluarga Harapan adalah salah satu program yang memberikan bantuan langsung tunai kepada keluarga sangat miskin, jika mereka memenuhi persyaratan yang terkait dengan upaya peningkatan kualitas sumberdaya manusia. Tujuan umum PKH ini adalah untuk mengurangi angka dan memutus rantai kemiskinan, meningkatkan kualitas sumber daya manusia, serta merubah perilaku keluarga sangat miskin yang relative kurang mendukung peningkatan kesejahteraan. ${ }^{42}$

Program Keluarga Harapan (PKH) merupakan salah satu program penanggulangan kemiskinan yang masuk kluster program perlindungan dan bantuan sosial yang ditujukan kepada Rumah Tangga Sangat Miskin (RTSM). Apabila dibanding dengan program lain $\mathrm{PKH}$ penerima bantuan ditetapkan berdasarkan data BPS (PPLS) kemudian diverifikasi oleh pendamping $\mathrm{PKH}$ baru ditetapkan sebagai calon peserta PKH.

Program yang merupakan kerjasama lintas kementerian ini, pada tahap awal pelaksanaan program ada anggapan bahwa program ini kelanjutan dari program Bantuan Langsung Tunai yang memberikan bantuan tunai tanpa syarat. Namun berbeda dengan BLT, program ini mewajibkan RTSM harus memeriksakan ibu hamil dan balita ke layanan kesehatan seperti Posyandu dan Puskesmas dan menyekolahkan anaknya di sekolah SD dan SMP.

41 Sri Edi Swasono, Indonesia dan Doktrin Kesejahteraan Sosial. (Jakarta: Perkumpulan PraKarsa, 2005), hlm. 37

${ }^{42}$ Kadek Dina Indriani, Analisis Pemanfaatan Program Keluarga Harapan (Pkh) Terhadap Peningkatan Kesejahteraan Masyarakat Miskin di Kecamatan Buleleng Tahun 2011-2015, (e-journal Jurusan Pendidikan Ekonomi Vol: 10 No: 2 Tahun: 2017), hlm. 3 
Proses dari Program Keluarga Harapan tidak mempertimbangkan permasalahan yang dialami oleh setiap individu. Analisis masalah yang dilakukan tidak mengerucut pada kebutuhan sebenarnya, hal ini terlihat pada Program Keluarga Harapan, di mana program ini langsung begerak pada bidang pendidikan dan kesehatan tanpa mengetahui permasalahan yang dialami individu. Dalam beberapa penelitian, ditemukan bahwa $\mathrm{PKH}$ ini telah memberikan kemudahan pada keluarga miskin untuk menyekolahkan anaknya, meskipun pada kenyataannya belum memberikan perubahan penghidupan kepada keluarga miskin tersebut. Sebagai salah satu contoh dalam upaya untuk menyekolahkan anak, keluarga miskin mampu untuk membayar biaya sekolah namun tidak mampu untuk memberikan uang jajan maupun menempuh jarak sekolah yang cukup jauh dari tempat tinggal. ${ }^{43}$

Bantuan dana tunai PKH diberikan kepada ibu atau perempuan dewasa (nenek, bibi atau kakak perempuan) dan selanjutnya disebut Pengurus Keluarga. Dana yang diberikan kepada pengurus keluarga perempuan ini bertujuan meningkatkan kualitas pendidikan dan kesehatan penerima bantuan. Pengecualian dari ketentuan diatas dapat dilakukan pada kondisi tertentu, misalnya bila tidak ada perempuan dewasa dalam keluarga maka dapat digantikan oleh kepala keluarga. Sebagai bukti kepesertaan PKH, KSM diberikan Kartu Peserta PKH. Uang bantuan dapat diambil oleh Pengurus Keluarga di Kantor Pos terdekat dengan membawa Kartu Peserta PKH dan tidak dapat diwakilkan. Sebagian peserta $\mathrm{PKH}$ menerima bantuan melalui rekening bank (BRI).

Rumah tangga masyarakat memegang peranan penting dalam pembangunan rumah tangga, dimana pengeluaran rumah tangga memiliki kontribusi langsung terhadap pembangunan manusia, seperti makanan,

\footnotetext{
${ }^{43}$ Syahputra Adisanjaya dll, Program Keluarga Harapan (PKH): Antara Perlindungan Sosial dan Pengentasan Kemiskinan, Prosiding KS: Riset \& PKM Volume: 4 ISSN: 2442-4480, hlm. 91
}

kesehatan dan pendidikan. Kesejahteraan rumah tangga ditentukan oleh pendapatan. Penduduk miskin akan lebih banyak atau bahkan seluruh pendapatannya digunakan untuk kebutuhan makanan, dibandingkan penduduk kaya. Akibatnya penduduk miskin tidak memiliki kesempatan untuk mendapatkan pendidikan dan pelayanan kesehatan yang layak jika hanya mengandalkan pendapatanya. Pemerintah meluncurkan program khusus yang diberi nama Program Keluarga Harapan (PKH).

Menurut Dirjen Bantuan dan Jaminan Sosial PKH dirancang untuk membantu penduduk miskin kluster terbawah berupa bantuan bersyarat yang terkait dengan upaya peningkatan kualitas sumber daya manusia yang terfokus pada pendidikan dan kesehatan. PKH ini dijalankan sebagai pelaksanaan dari UU No. 40 Tahun 2009 tentang kesejahteraan sosial. Inpres no.3 tahun 2010 tentang program pembangunan yang berkeadilan. Perpres No 15 Tahun 2010 tentang percepatan penanggulangan kemiskinan dan UU No. 39 Tahun 1999 tentang hak asasi manusia. ${ }^{44}$

Pemanfaatan Program Keluarga Harapan dalam peningkatan kesejahteraan masyarakat miskin di Indonesia mampu member konstribusi yang serius dan signifikan dalam upaya membantu keluarga sangat miskin, dengan adanya Program Keluarga Harapan ini masalah pendidikan dasar, kesehatan dasar, bahkan tingkat penghasilan keluarga dapat diperhatikan, dilihat dari penurunan jumlah penduduk miskin sebanyak $32 \%$ dari pelaksanaan Program Keluarga Harapan di Indonesia dengan hasil yang didapat demikian pemanfaatan Program Keuarga Harapan penerima bantuan tunai bersyarat ini dijamin kesejahteraannya dimulai dari kesehatan, pendidikan, biaya hidup, ibu hamil, anak balita, anak sekolah, lansia terlantar, kecacatan, rastra (beras sejahtera), rumah, KUBE (Kelompok Usaha Bersama), subsidi gas, subsidi listrik, dan subsidi pupuk dengan

44 Dinas Sosial. Kajian Program Keluarga Harapan. (Jakarta: Direktorat Jendral Anggaran. 2015) 
dipantau pelaksanaanya oleh setiap pendamping untuk melancarkan target dari tujuan Program Keluarga Harapan dan meminimalisir penyimpangan atau kesalahgunaan data yang diberikan. Maka dari itu kepedulian dan prioritas pemerintah terhadap arah dan sasaran pembangunan untuk kesejahteraan masyarakat miskin demi mengentaskan kemiskinan, pemanfaatan program keluarga harapan ini sangat baik dan layak untuk berkelanjutan dan berkesinambungan sesuai tujuan PKH untuk mensejahteraan masyarakat miskin. ${ }^{45}$

\section{Penutup}

Pemerintah dan masyarakat haruslah saling membantu dan menjaga koordinasi agar terlaksananya program-program yang telah dicanangkan oleh pemerintah desa demi meningkatkan kesejahteraan masyrakatnya agar dapat benar-benar terealisasikan, karena suatu desa dikatakan makmur dan juga sejahtera ketika masyarakat yang ada di dalamnya juga sejahtera. Pemerintah masih perlu terus meningkatkan kepeduliannya akan kesejahteraan masyarakat desanya karena hingga saat ini masyarakat masih belum merasakan peningkatan kesejahteraan yang signifikan. Pembuatan skala prioritas bertujuan mendapatkan prioritas-prioritas permasalahan yang harus dipecahkan. Teknik yang digunakan dalam membuat skala prioritas adalah ranking dan pembobotan. Menyusun alternatif tindakan pemecahan masalah yang layak dilakukan dengan tujuan menemukan alternatif tindakan pemecahan masalah yang ada dengan memperhatikan potensi akar yang layak. Menetapkan tindakan yang layak, pada tahapan ini pengkajian dititik beratkan pada menentukan / memilih alternatif tindakan maslah yang paling layak digunakan untuk memecahkan masalah yang ada. Pada tahapan ini juga dikaji dan dipilih kegiatan pembangunan skala desa dan kegiatan pembangunan skala kabupaten.

45 Dinas Sosial.Pedoman Umum Program Keluarga Harapan. (Denpasar: Dinas Sosial. 2015)

\section{Daftar Pustaka}

Adasiha Arwan dkk, Pengaruh Kebijakan Pemerintah Terhadap Tingkat Kewirausahaan di Indonesia (Studi pada Program Kredit Usaha Rakyat Periode Tahun 2008-2014), Malang: Jurnal Administrasi Bisnis (JAB) Vol. 60 No. 3 Juli 2018

Arifin Johan, Etika Bisnis Islami Semarang: Walisongo Press, 2009

Bachtiar Chamsyah, Kemiskinan Sebagai Isu Global.

Artikel.

http://www.socialwelfare.fisip.ui.ac. id

Badan Perencanaan Pembangunan Nasional. 2003. Infrastruktur Indonesia; Sebelum, Selama dan Pasca Krisis. Jakarta: Perum Percetakan Negara RI.

Baskoro Wicaksono, Peran Pemerintah Dalam Meningkatkan Kesejahteraan Petani Salak di Desa Tinjoman Lama Kecamatan Padangsidimpuan Hutaimbaru Kota Padang Sidimpuan Tahun 2014, Hasil Penelitian Jurusan Ilmu Pemerintahan FISIP Universitas Riau, 2014

Berger, PL dan T. Luckmann. 1982. Realitas Konstrukti Sosial, diterjemahkan oleh Syarwani, dkk. Jakarta Sinar Harapan. 1982

Dahlan Al Barry. Kamus Modern Bahasa Indonesia. Yogyakarta: Arkola. 1994

Dina Damayanti, Peran Pemerintah Daerah Terhadap Perkembangan Koperasi di Kabupaten Kendal, jurnal Majalah Ilmiah Inspiratif, Vol.2 No.2 Januari 2016

Dinas Sosial. Kajian Program Keluarga Harapan. Jakarta: Direktorat Jendral Anggaran. 2015

Dinas Sosial.Pedoman Umum Program Keluarga Harapan. Denpasar: Dinas Sosial. 2015

Edi Suharto, Membangun Masyarakat Memberdayakan Rakyat (Kajian Strategis Pembangunan 
Kesejahteraan Sosial \& Pekerjaan Sosial), Bandung: PT Refika Aditama. 2005

Garda Maeswara, Biografi Prolitik Susilo Bambang Yudhoyono, Jakarta: Penerbit Narasi, 2009

Hendro Darmawan, Kamus Ilmiah Populer Lengkap, Yogyakarta: Bintang Cemerlang, 2013

Hoetomo, Kamus Lengkap Bahasa Indonesia, Surabaya: Mitra Pelajar, 2005

Horton dan Hunt, lihat dalam Damsar, dan Indrayani, Pengantar Sosiologi Ekonomi, Jakarta: Kencana, 2009

http://bulog.go.id/,"Program Beras untuk Keluarga Miskin”, hlm..4-6, diakses 17 Juli 2018

http://www.tnp2k.go.id/id,

"Beras

Raskin”,hlm.1, diakses 17 Juli 2018

http://www.tnp2k.go.id/tanya-jawab-

program-raskin/page1, diakses 24 Juli 2018

Isbandi Rukminto Adi. Ilmu Kesejahteraan Sosial dan Pekerjaan Sosial: Pengantar PadaPengertian dan Beberapa Pokok Bahasan. Jakarta: FISIP UI Press 2005

Kadek Dina Indriani, Analisis Pemanfaatan Program Keluarga Harapan (Pkh) Terhadap Peningkatan Kesejahteraan Masyarakat Miskin di Kecamatan Buleleng Tahun 2011-2015, (e-journal Jurusan Pendidikan Ekonomi Vol: 10 No: 2 Tahun: 2017), hlm. 3

Kamus besar, definisi peran, dalamwww.artikata.com, diakses pada tanggal 8 Maret 2015, pukul 17.00.

Kementerian dalam Negeri Republik Indonesia, Penjelasan I : Pemantauan, Pengawasan Evaluasi, Audit dan Pelaporan (PEtunnjuk Teksis Operasional), Direktorat Jendral Pemberdayaan Masyarakat dan Desa, 2011

Khairuddin, Sosiologi Keluarga, Yogyakarta: Liberty, 2002
Konsep-dasar-pemerintah-danpemerintahan.html, diakses pada tanggal 21 April 2015 pukul 19.55 WIB.

M. Umer Chapra, Islam Pembangunan Ekonomi, Jakarta, Gema Insani Press, 2000

Moh. Thahah Hasan, Islami dalam Perspektif Sosio Kultural, Jakarta: Lantabora Press, 2005

Mustafa Edwin Nasution, dkk, Pengenalan Ekonomi Isam, Jakarta: Kencana, 2006

Nur Chamid, Jejak Langkah Sejarah Pemikiran Ekonomi Islam, Yogyakarta: Pustaka Pelajar, 2010

Nurul Hak, Ekonomi Islam Hukum Bisnis Syari'ah, Yogyakarta: Teras, 2011

Nurul Huda, dkk., Ekonomi Pembangunan Islam, Jakarta: Kencana, 2015

Rahmaniar dkk, Peran Pemerintah Terhadap Lanjut Usia Pada Panti Sosial Tresna Werdha Sinta Rangkang Di Kota Palangka Raya, IAIN Palangka RayaJurnal Al-Qardh, Vol. 2, No. 4, Desember 2016

Ruslan Abdul Ghofur Noor, Konsep Distribusi dalam Ekonomi Islam, Yogyakarta: Pustaka Pelajar, 2013

Sayyid Qutb, Dirasah Islamiyah. Kairo: alMa`arif, 1967

Sitti Mawar, Fungsi Kebijakan Ekonomi Pemerintah Kota Banda Aceh Terhadap Kesejahteraan Masyyarakat Menurut Ibnu Kaldum, Jurnal UIN Ar-Raniry Banda AcehProdi Ilmu Hukum Pada Fakultas Syari'ah dan Hukum, 2016

Sri Edi Swasono, Indonesia dan Doktrin Kesejahteraan Sosial. Jakarta: Perkumpulan PraKarsa, 2005

Sulastomo, Sistem Jaminan Nasional: Mewujudkan Amanat Konsitusi, Jakarta: PT.Gramedia Pustaka Utama, 2011

Syahputra Adisanjaya dll, Program Keluarga Harapan (PKH): Antara Perlindungan Sosial dan Pengentasan Kemiskinan, Prosiding 
KS: Riset \& PKM Volume: 4 Teori peran menurut Dougherty dan ISSN: 2442-4480,

Syahputra Adisanjaya dll, Program

Keluarga Harapan (PKH): Antara

Perlindungan Sosial dan

Pritchard, dalam www.google.co.id, definisi peranmenurut para ahli, diakses pada tanggal 8 Maret 2015, pukul 19.25.

Pengentasan Kemiskinan, Prosiding

KS: Riset \& PKM Volume: 4

ISSN: 2442-4480

www.menkokesra.go.id., diakses pada tanggal 21 April 2015 pukul 16.24 WIB. 